\title{
EVALUATION OF ENZYMIC AND NON-ENZYMIC ANTIOXIDANT LEVELS IN VERNONIA CINEREA EXTRACTS
}

\author{
NISHADH ABUBAKKER* \\ Department of Food Processing \& Engineering, Karunya Institute of Technology and Sciences, Coimbatore, Tamil Nadu, India. \\ Email: nishadh@karunya.edu
}

Received: 19 August 2017, Revised and Accepted: 02 April 2018

\begin{abstract}
Objective: The objective of this study was to evaluate the enzymic and non-enzymic antioxidant levels in various solvent extracts of Vernonia cinerea leaves.

Methods: The fine powder of leaf (180 g) was extracted successively with methanol, ethanol, petroleum ether $\left(40-60^{\circ} \mathrm{C}\right)$, benzene, acetone, ethyl acetate, chloroform, and aqueous in a Soxhlet extractor for $18 \mathrm{~h}$. The extracts were concentrated under reduced pressure at low temperature (40$50^{\circ} \mathrm{C}$ ), and the extracts were analyzed for the antioxidant enzymes such as catalase (CAT), superoxide dismutase (SOD), peroxidise, glutathione S-transferase (GST), glutathione peroxidase (GPx), polyphenol oxidase, glutathione (GSH) reductase, and glucose-6-phosphate dehydrogenase and non-enzymic antioxidants such as Vitamin A, C, E, reduced GSH, and total phenol.
\end{abstract}

Results: Significant activities of enzymic antioxidants such as CAT (23.68 $\mu$ mole of $\mathrm{H}_{2} \mathrm{O}_{2}$ decomposed/min/mg protein, SOD (19.75 inhibition of 50\% nitrite form/min/mg protein), and GST (73.28 $\mu$ mole of 1-chloro-2,4-dinitrobenzene conjugate formed/min) were observed higher in the methanolic extracts. Whereas, ethanolic extract exhibits maximum activity of GPx (1.054 $\mu$ mole of GSH utilized/min) and Px (102.1 $\mu$ mole of pyrogallol oxidized/ $\mathrm{min} / \mathrm{mg}$ protein). Total GSH (172.3 $\mu \mathrm{M} / \mathrm{g})$, Vitamin E (23.76 $\mu \mathrm{M} / \mathrm{g})$, and total phenols were significantly predominant in the ethanolic extracts followed by methanol and ethyl acetate extracts.

Conclusion: V. cinerea seems to be a promising plant in respect of its antioxidant potential, there is a lot more to be done to understand the mechanisms behind these effects as well as to employ them as possible therapeutic agents.

Keywords: Vernonia cinerea, Antioxidants, Glutathione, Total phenol.

(C) 2018 The Authors. Published by Innovare Academic Sciences Pvt Ltd. This is an open access article under the CC BY license (http://creativecommons. org/licenses/by/4. 0/) DOI: http://dx.doi.org/10.22159/ajpcr.2018.v11i7.22109

\section{INTRODUCTION}

Free radicals are chemically unstable atoms that cause damage to lipid cells, proteins, and DNA, as a result of imbalance between the generations of reactive oxygen species (ROS) and the antioxidant enzymes [1]. Free radicals and ROS are well-known inducers of cellular and tissue pathogenesis, leading to several human diseases such as asthma, cancer, cardiovascular disease, cataract, diabetes, gastrointestinal inflammatory disease, liver disease, muscular degeneration, and other inflammatory process [2]. ROS are continuously produced during cell metabolism and under normal conditions; they are scavenged and converted to nonreactive species by different intracellular enzymatic and non-enzymatic antioxidant system [3]. Antioxidants can be classified into two major classes, i.e., enzymatic and non-enzymatic. The enzymatic antioxidants are produced endogenously which include superoxide dismutase (SOD), catalase (CAT), and glutathione peroxidase (GPx). The non-enzymatic antioxidants include alphatocopherols, carotenoids, ascorbic acid, flavonoids, and tannins which are obtained from natural plant sources. A wide range of antioxidants from both natural and synthetic origin has been proposed for the use in the treatment of various human diseases [4].

Vernonia cinerea (L.) less belonging to the family Asteraceae is an annual plant widely distributed in India, Bangladesh, Sri Lanka, and Malay Island [5]. $V$. cinerea is one of the species of Vernonia found in Nigeria, and it is known as a weed [6]. The plant is extensively used in indigenous medicine in stomach aches, and for cold, asthma and bronchitis [7]. The Ayurveda Pharmacopoeia of India recommends the plant for the treatment of intermittent fever, filariasis, blisters, boils, and vaginal discharges. The root of the plant is used traditionally for the treatment of all types of eruptive boils, and the juice is used for faster healing of accidental wounds, filariasis, and toxic viral fevers. The seeds are used in dysuria and to treat colic in the form of decoction [8]. Young leaves of the plant are used for the treatment of tonsillitis [9]. The leaf juice extract is used to treat skin diseases and the leaf extract for treating dysentery in children. Besides these, the plant is used in smoking cessation, cough, fever, malaria, urinary calculi, and leprosy [10]. The plant possesses hepatoprotective [11], antibacterial [12], antioxidant [13], anthelmintic, anti-inflammatory, analgesic, antipyretic [14,15], antiflatulent, antispasmodic [7], and antidiuretic properties [16].

Epidemiologic studies that analyze the health implications of dietary components rely on the intake estimates in sample populations found in databases that list the component's content in commonly consumed foods. Therefore, the availability of appropriate and complete food composition data is crucial. Due to the chemical diversity of antioxidant compounds present in plants, complete databases on plant antioxidant content are not yet available. Differences between each solvent type extracts could be explained by: (a) Various substitution patterns (mainly hydroxylation/glycosylation) of constituents, (b) various constituents ratio, and (c) various total contents of antioxidant active substances in extracts [17]. Therefore, the present study has been undertaken to evaluate the antioxidant status in different extracts of $V$. cinerea leaves.

\section{METHODS}

Plant collection

$V$. cinerea leaves were collected in September 2015 from the Western Ghats of Anamalai Hills, Valparai taluk of Coimbatore district, Tamil Nadu, India. They were identified and authenticated by the experts 
at the Department of Botany, Kongunadu Arts and Science College, Coimbatore, where the voucher specimen has been deposited.

\section{Preparation of the plant extract}

The fresh leaves were washed with distilled water and shade dried for a week and powdered coarsely by hand. Then, they were finely powdered mechanically using an electric grinder and passed through 40 mesh sieve and stored in airtight containers. The powder (180 g) was extracted successively with methanol, ethanol, petroleum ether $\left(40-60^{\circ} \mathrm{C}\right)$, benzene, acetone, ethyl acetate, chloroform, and aqueous in a Soxhlet extractor for $18 \mathrm{~h}$. The extracts were concentrated under reduced pressure at low temperature $\left(40-50^{\circ} \mathrm{C}\right)$. The extractive values were $34.5,26.3,0.9,1.8,18.4,14.5,20$, and $12.5 \%$, respectively.

\section{Enzymic and non-enzymic antioxidant assays}

The catalytic activities of antioxidant enzymes CAT [18], SOD [19], peroxidise [20], glutathione S-transferase (GST) [21], GPx [22], polyphenol oxidase (PPO) [23], glucose-6-phosphate dehydrogenase [24], and enzyme protein [25] were evaluated in eight different solvent extracts.

The non-enzymic antioxidants, namely Vitamin A [26], C [27], E [28], reduced glutathione (GSH) [29], and total phenol [30] were also estimated in selected extracts of $V$. cinerea.

\section{RESULTS AND DISCUSSION}

Table 1 summarizes the activities of SOD, CAT, GPx, GST, and Px were observed higher in the methanolic and ethanolic extracts of $V$. cinerea compared to that of other extracts. Free radical scavenging enzymes such as SOD, CAT, GPx, GSH reductase, and GST are the first line of defense against oxidative injury decomposing $\mathrm{O}_{2}{ }^{\cdot}$ and $\mathrm{H}_{2} \mathrm{O}_{2}$ before interacting to form the more reactive hydroxyl radical $(\mathrm{OH} \bullet)$, the equilibrium between these enzymes is an important process for the effective removal of oxidative stress in intracellular organelles [31].

Significant activities of G6PD were observed higher in the ethanolic extract when compared to that of other extracts (Table 1). G6PD is a cytosolic NADP-dependent enzyme. This generates NADPH which is necessary for the regeneration of reduced GSH from oxidized GSH. Maintenance of GSH in the reduced state is an important function of G6PD. The PPO activities from Table 1 were found to be higher in methanol and ethyl acetate extracts compared to that of other extracts.

There is good evidence, suggesting the protective effect of SOD and CAT which are scavenger enzymes involved in free radical scavenging mechanism on lipid peroxidation [32]. CAT is an iron-containing enzyme catalyzing the dismutation of $\mathrm{H}_{2} \mathrm{O}_{2}$ into $\mathrm{O}_{2}$ and $\mathrm{H}_{2} \mathrm{O}$. It is a major antioxidant enzyme in curtailing the peroxidative damage in biological system. The enzyme is found in all aerobic eukaryotes and is important in the removal of $\mathrm{H}_{2} \mathrm{O}_{2}$ generated in peroxisomes by oxidases and also in glyoxylate cycle and purine catabolism. Various isoforms are also reported in cytosol and mitochondria [33]. GPx, a selenium enzyme, catalyzes the destruction of $\mathrm{H}_{2} \mathrm{O}_{2}$ and lipid hydroperoxides by reaction with reduced GSH to form GSH disulfide and the reduction product of hydroperoxide [34]. GST is a family of isoenzymes which participate in the conjugations of GSH with the products of metabolites of xenobiotic substances such as cytochrome p450 systems, increasing their elimination from organisms in the form of mercapturates [35]. Pxs are a group of enzymes that catalyze oxidation-reduction reactions. As such, they are classified as oxidoreductases. Pxs reduce $\mathrm{H}_{2} \mathrm{O}_{2}$ to water while oxidizing a variety of substrates. Thus, Pxs are oxidoreductases which use $\mathrm{H}_{2} \mathrm{O}_{2}$ as electron acceptor for catalyzing different oxidative reactions.

Polyphenols exhibit a wide range of biological effects as a consequence of their antioxidant properties. They inhibit low-density lipoprotein (LDL) oxidation in vitro [36]. Moreover, LDL isolated from volunteers supplemented with red wine or red wine polyphenols exhibited reduced susceptibility to oxidation [37]. Thus, polyphenols probably protect LDL oxidation in vivo with significant consequences in atherosclerosis and also protect DNA from oxidative damage with important consequences in the age-related development of some cancers [38]. The enzymic protein concentration from Table 1 was found to be high in methanol, ethanol, and chloroform extracts compared to that of other extracts.

\section{Non-enzymic antioxidants}

Total GSH (Table 2) was predominant in the methanol and ethanolic extracts. The levels of Vitamin A and Vitamin C were found to be higher in the ethyl acetate extract, whereas chloroform and ethanol extracts exhibited high levels of Vitamin E. High levels of GSH and GPx play an important role in the prevention of lipid peroxidation. GSH is an important constituent of detoxification mechanism operating in biological system. GSH can function as an antioxidant in many ways. It can react chemically with singlet oxygen, superoxides, and hydroxyl radicals, and therefore, function directly as free radical scavenger. GSH may stabilize membrane structure by removing acyl peroxides formed by lipid peroxidation [39]. Ascorbic acid functions as the main water-soluble antioxidant protecting tissue from oxidative damage. It acts as a direct scavenger of free radicals and act as a reductant in enzymatic reactions [40].

Vitamin A and related retinols have been reported to increase immunity to tumors by several mechanisms including enhancement of cytotoxic $\mathrm{T}$ lymphocyte activity, which has been exploited in the treatment of HIV infection [41]. A number of observations have long supported the concept that Vitamin C may act as an antioxidant [42]. It acts as the main radical acceptor from Vitamin E [43]. It suppresses the formation of carcinogens such as nitrosamines and quinines [44]. A preparation containing green tea extract, ascorbic acid, sunflower seed extract, carotene, and natural Vitamin $\mathrm{E}$ has been designed as a model "universal antioxidant" that may offer protection through its scavenging action on a wide range of free radicals both water soluble and fat soluble [45].

The tocopherols, specifically, $\alpha$-tocopherol (Vitamin E), have been studied extensively in mammalian research as membrane stabilizers

Table 1: Enzymic antioxidant levels in various extracts of $V$. cinerea

\begin{tabular}{|c|c|c|c|c|c|c|c|c|}
\hline Extracts & CAT & SOD & GPx & GST & Px & PPO & G6PD & Enzymic protein \\
\hline Methanol & $23.68^{a}$ & $19.75^{\mathrm{a}}$ & $0.920^{\mathrm{b}}$ & $73.28^{\mathrm{a}}$ & $96.96^{a}$ & $2.654^{\mathrm{a}}$ & $4.037^{\mathrm{e}}$ & $0.468^{\mathrm{a}}$ \\
\hline Ethanol & $22.60^{\mathrm{a}}$ & $19.08^{\mathrm{a}}$ & $1.054^{\mathrm{a}}$ & $69.93^{\mathrm{a}}$ & $102.1^{\mathrm{a}}$ & $1.494^{\mathrm{b}}$ & $7.284^{\mathrm{a}}$ & $0.476^{\mathrm{a}}$ \\
\hline P.E & $6.975^{f}$ & $11.50^{\mathrm{d}}$ & $0.301^{\mathrm{e}}$ & $26.90^{\mathrm{e}}$ & $38.94^{\text {de }}$ & $0.256^{\mathrm{d}}$ & $1.006^{\mathrm{g}}$ & $0.096^{\mathrm{d}}$ \\
\hline Benzene & $1.058^{\mathrm{e}}$ & $5.602^{\mathrm{e}}$ & $0.100^{\mathrm{g}}$ & $12.95^{f}$ & $34.90^{\mathrm{e}}$ & $0.420^{c}$ & $1.181^{\mathrm{f}}$ & $0.091^{\mathrm{d}}$ \\
\hline Acetone & $17.12^{\mathrm{b}}$ & $13.50^{c}$ & $0.366^{\mathrm{d}}$ & $32.04^{\mathrm{d}}$ & $61.69^{b}$ & $1.594^{\mathrm{b}}$ & $4.162^{\mathrm{e}}$ & $0.293^{c}$ \\
\hline Ethyl acetate & $17.12^{\mathrm{b}}$ & $14.77^{\mathrm{b}}$ & $0.508^{\mathrm{c}}$ & $55.32^{\mathrm{b}}$ & $48.40^{\mathrm{d}}$ & $2.545^{\mathrm{a}}$ & $5.053^{\mathrm{b}}$ & $0.349^{\mathrm{b}}$ \\
\hline Chloroform & $11.05^{c}$ & $13.10^{\mathrm{bc}}$ & $0.302^{\mathrm{e}}$ & $39.63^{c}$ & $64.96^{\mathrm{b}}$ & $1.503^{\mathrm{b}}$ & $4.283^{\mathrm{d}}$ & $0.475^{\mathrm{a}}$ \\
\hline
\end{tabular}

Values are expressed as mean of three replicates. Means followed by a common letter are not significantly different at the $5 \%$ level by DMRT, CAT - $1 \mu$ mole of $\mathrm{H}_{2} \mathrm{O}_{2}$ decomposed $/ \mathrm{min} / \mathrm{mg}$ protein, SOD - inhibition of $50 \%$ nitrite form $/ \mathrm{min} / \mathrm{mg}$ protein, GPx - $1 \mu$ mole of GSH utilized/min, GST - 1 $\mu$ mole of 1-chloro-2,4-dinitrobenzene conjugate formed/min, Px - $1 \mu$ mole of pyrogallol oxidized/min/mg protein, PPO - 0.01 O.D change/min/mg protein, G6PD - 0.01 0.D change/min/mg protein, Enzymic protein - mg/g. V. cinerea: Vernonia cinerea, DMRT: Duncan's multiple range test, CAT: Catalase, SOD: Superoxide dismutase, GPx: Glutathione peroxidase, GST: Glutathione S-transferase, Px: Peroxidase, PPO: Polyphenol oxidase 
Table 2: Non-enzymic antioxidant levels in various extracts of $\mathrm{V}$. cinerea

\begin{tabular}{|c|c|c|c|c|c|}
\hline Extracts & Total GSH & Vitamin A & Vitamin C & Vitamin E & Total phenols \\
\hline Methanol & $163.9^{a}$ & $8.426^{b}$ & $2.244^{\mathrm{b}}$ & $20.60^{\mathrm{b}}$ & $71.11^{\mathrm{a}}$ \\
\hline Ethanol & $172.3^{\mathrm{a}}$ & $7.829^{c}$ & $1.428^{\mathrm{d}}$ & $23.76^{a}$ & $70.04^{\mathrm{a}}$ \\
\hline P.E & $84.23^{\mathrm{e}}$ & $5.406^{f}$ & $1.377^{\mathrm{e}}$ & $10.30^{\mathrm{e}}$ & $34.55^{\mathrm{e}}$ \\
\hline Benzene & $122.54^{c}$ & $5.917^{e}$ & $0.918^{f}$ & $15.05^{c}$ & $42.24^{\mathrm{d}}$ \\
\hline Acetone & $97.08^{d}$ & $6.820^{\mathrm{d}}$ & $1.836^{c}$ & $10.30^{\mathrm{e}}$ & $31.90^{\mathrm{f}}$ \\
\hline Ethyl acetate & $59.53^{f}$ & $9.671^{\mathrm{a}}$ & $3.417^{\mathrm{a}}$ & $11.09^{d}$ & $46.55^{c}$ \\
\hline Chloroform & $136.6^{b}$ & $7.994^{c}$ & $0.816^{\mathrm{g}}$ & $22.17^{\mathrm{a}}$ & $33.60^{\mathrm{e}}$ \\
\hline
\end{tabular}

Values are expressed as mean of three replicates. Means followed by a common letter are not significantly different at the $5 \%$ level by DMRT, Total GSH - $\mu$ M/g, Vitamin A and E - $\mu \mathrm{g} / \mathrm{g}$, Vitamin C - mg/g, Total phenol - $\mu \mathrm{g} / \mathrm{g}$. V. cinerea: Vernonia cinerea, DMRT: Duncan's multiple range test, GSH: Glutathione

and multifaceted antioxidants that scavenge oxygen free radicals, lipid peroxyradicals, and singlet oxygen [46]. Vitamin $\mathrm{E}$ is the important hydrophobic chain-breaking antioxidant that protects membrane and plasma lipoprotein from free radicals [47]. Due to its dietary importance, tocopherol levels have been documented extensively in plant tissue [48]. The total phenols were predominant in the methanol and ethanolic extracts. The presence of phenolic compounds in the plant indicates that these plants may have antimicrobial agents. These antioxidants contribute significantly toward the biological activities such as hypoglycemic, antidiabetic, antimicrobial, antioxidant, anti-inflammatory, anticarcinogenic, antimalarial, and antileprosy activities [49]

\section{CONCLUSION}

The results of this study showed that the level of antioxidants significantly varies with different solvent extracts. $V$. cinerea seems to be a promising plant in respect of its antioxidant potential; there is a lot more to be done to understand the mechanisms behind these effects as well as to employ them as possible therapeutic agents.

\section{CONFLICTS OF INTEREST}

None.

\section{REFERENCES}

1. Manian R, Anusuya N, Siddhuraju P, Manian S. The antioxidant activity and free radical scavenging potential of two different solvent extracts of Camellia sinensis (L.) O. Kuntz, Ficus bengalensis L. and Ficus racemosa L. Food Chem 2008;107:1000-7.

2. Sen S, Chakraborty R, Sridhar C, Reddy YS. Free radicals, antioxidants, diseases and phytomedicines: Current status and future prospect. Int J Pharm Sci Rev Res 2010;3:91-100.

3. Dröge W. Free radicals in the physiological control of cell function. Physiol Rev 2002;82:47-95.

4. Shao HB, Chu LY, Lu ZH, Kang CM. Primary antioxidant free radical scavenging and redox signaling pathways in higher plant cells. Int $\mathrm{J}$ Biol Sci 2007;4:8-14.

5. Harbone JB. Phytochemical Methods: A Guide to Modern Technique of Plant Analysis. London: Chapman and Hall; 1998.

6. Oladele FA. Leaf epidermal features in Vernonia amygdalina and Vernonia cinerea. Nig J Bot 1990;3:71-7.

7. Kirtikar KR, Basu BD. Indian Medicinal Plants. New Delhi: Sri Satguru Publication; 2000

8. Varghese KJ, Anila J, Nagalekshmi R, Resiya S, Dasapushpam SJ. The traditional uses and the therapeutic potential of ten sacred plants of Kerala state in India. Int J Pharm Sci Res 2010;1:50-9.

9. Hamill FA, Apio S, Mubiru NK, Bukenya-Ziraba R, Mosango M, Maganyi OW, et al. Traditional herbal drugs of southern Uganda, II: Literature analysis and antimicrobial assays. J Ethnopharmacol 2003;84:57-78.

10. Sonibare MA, Aremu OT, Okorie PN. Antioxidant and antimicrobial activities of solvent fractions of Vernonia cinerea (L.) less leaf extract. Afr Health Sci 2016;16:629-39.

11. Nishadh A, Gokilaveni C, Selvi V, Mahalakshmi, R. Antioxidant activities of ethanolic extract of Vernonia cinerea in carbon tetrachloride induced hepatic damage in rats. Int J Curr Res 2013;5:1441-4.

12. Yoga LL, Darah I, Sasidharan S, Jain K. Antimicrobial activity of Emilia sonchifolia DC, Tridax procumbens L. and Vernonia cinerea L. of Asteraceae Family: Potential as food preservatives. Malay J Nutr 2009; 15:223-31

13. Nishadh A, Selvi V, Mahalakshmi R. In-vitro antioxidant and phytochemical screening of various extracts of Vernonia cinerea leaves. Int J Drug Dev Res 2013;5:229-33.

14. Misra TN, Singh RS, Upadhyay J, Srivastava R. Chemical constituents of Vernonia cinerea. Part I. Isolation and spectral studies of triterpenes. J Nat Prod 1984;47:368-72.

15. Iwalewa EO, Iwalewa OJ, Adeboye JO. Analgesic, antipyretic, antiinflammatory effects of methanol, chloroform and ether extracts of Vernonia cinerea less leaf. J Ethnopharmacol 2003;86:229-34

16. Mazumder UK, Gupta M, Manikandan L, Bhattacharya S, Haldar PK, Roy S. Evaluation of anti-inflammatory activity of Vernonia cinerea extract in rats. Phytomedicine 2003;10:185-8.

17. Sersen F, Mucaji P, Spilkova J, Valko V, Haladova M, Eisenreichova E, et al. Solvent extracts from leaves of Cynara cardunculus, Philadelphus coronarius, Lilium candidum, Holodiscus discolor and Ligustrum vulgare. Acta Facult Pharm Univ Comenianae 2006;53:262-7.

18. Sinha AK. Colorimetric assay of catalase. Anal Biochem 1972;47:389-94.

19. Das K, Samantha L, Chainy GB. A modified spectrophotometric assay of superoxide radicals. Ind J Biochem Biophys 2000;37:201-4.

20. Addy SK, Goodman RN. Polyphenol oxidase and peroxidase activity in apple leaves inoculated with a virulent or an avirulent strain of Erwinia amylovora. Ind Phytopathol 1972;25:575-9.

21. Habig WH, Pabst MJ, Jacoby WB. Glutathione-S-transferase the first enzymatic step in mercapturic acid formation. J Biol Chem 1974;249:7130-9.

22. Rotruck JT, Pope AL, Ganther HE, Awanson AB, Hafeman DG, Hoeckstra WG. Selenium: Biochemical role as a component of glutathione peroxidase. Science 1979;179:588-90.

23. Sadasivam S, Manickam A. Biochemical Methods for Agricultural Sciences. New Delhi: Wiley Eastern Ltd.; 1992. p. 111-2.

24. Balinsky D, Bernstein RE. The purification and properties of glucose-6phosphate dehydrogenase from human erythrocytes. Biochim Biophys Acta 1963;67:313-5.

25. Lowry OH, Rosebrough NJ, Farr, AL, Randall RJ. Protein measurement with folin's phenol reagent. J Biol Chem 1951;193:265.

26. Neeld JB, Pearson WN. Macro and micromethods for the determination of serum vitamin A using trifluoroacetic acid. J Nutr 1963;79:454-62.

27. Omaye ST, Turnball TD, Sauberlich HE. Selected methods for the determination of ascorbic acid in animal cells, tissues and fluids. Methods Enzymol 1979;62:1-11.

28. Rosenberg HR. Chemistry and Physiology of Vitamins. New York: Inter Science Publishers Inc.; 1992. p. 452-3.

29. Moron MS, Depierre JW, Mannervik B. Levels of glutathione, glutathione reductase and glutathione S-transferase activities in rat lung and liver. Biochim Biophys Acta 1979;582:67-78.

30. Bray HG, Thorpe WV. Analysis of phenolic compounds of interest in metabolism. Methods Biochem Anal 1954;1:27-52.

31. Devaki T, Shivashangari KS, Ravikumar V, Govindaraju P. Effect of Boerhaavia diffusa on tissue antioxidant defense system during ethanol-induced hepatotoxicity in rats. J Nat Remedies 2005;5:102-7.

32. Chander R, Kapoor NK. High density lipoprotein is a scavenger of superoxide anions. Biochem Pharmacol 1990;40:1663-5

33. Scandalias JG. Response of plant antioxidant defence genes to environmental stress. Adv Genet 1990;28:1-41.

34. Jeyaprakash K, Chinnaswamy P. Effect of spirulina and liv-52 on cadmium induced toxicity in albino rats. Indian J Exp Biol 2005;43:773-81.

35. Ferrfira R, Candeias F, Simcesr F, Nascimeto J, Morais JC. Effect of hormone on liver mixed-function monooxygenases and glutathione 
enzyme action of wistar rats. J Ethanopharmacol 1997;58:21-30.

36. Frankel EN, Kanner J, German JB, Parks E, Kinsella JE. Inhibition of oxidation of human low-density lipoprotein by phenolic substances in red wine. Lancet 1993;341:454-7.

37. Nigdikar SV, Williams NR, Griffin BA, Howard AN. Consumption of red wine polyphenols reduces the susceptibility of low-density lipoproteins to oxidation in vivo. Am J Clin Nutr 1998;68:258-65.

38. Halliwell B, Gutteridge JM. Free Radicals in Biology and Medicine. $3^{\text {rd }}$ ed. Oxford: Oxford University Press; 1999. p. 237-48

39. Price A, Lucas PW, Lea PJ. Age dependent damage and glutathione metabolism in ozone fumigated barley: A leaf section approach. J Exp Bot 1990;41:1309-17.

40. Nagel E, Meyer A, Bartels M. Antioxidant vitamins in prevention of ischemia/reperfusion injury. Int J Vit Nutr Res 1997;67:298-306.

41. Tachibana K, Sone S, Tsubura E, Kishino Y. Stimulatory effect of vitamin A on tumoricidal activity of rat alveolar macrophages. $\mathrm{Br} \mathrm{J}$ Cancer 1984;49:343-8

42. Sies H. Oxidative stress, oxidant and anioxidants. Antioxidant activity of fruit exudate and C-methylated dihydrochalocones from Myrica Gale. Planta Med 1992;61:515-8.
43. Böhles H. Antioxidative vitamins in prematurely and maturely born infants. Int J Vitam Nutr Res 1997;67:321-8.

44. Tannenbaum SR, Wishnok JS. Inhibition of nitrosamine formation by ascorbic acid. Ann New York Acad Sci 1987;498:354-63.

45. Kumar M, Grammas P, Giacomelli F, Wiener J. Selective expression of c-mas proto-oncogene in rat cerebral endothelial cells. Neuroreport 1996;8:93-6.

46. Diplock AT, Xu GL, Yeow CL, Okikiola M. Relationship of tocopherol structure to biological activity, tissue uptake, and prostaglandin biosynthesis. Ann New York Acad Sci 1989;570:72-84.

47. Neogy M, Bhattacharya A. Qualitative screening of phytochemical and comparative study of dietary antioxidative properties of three commonly used leafy vegetables of West Bengal. Int J Pharm Pharm Sci 2015;7:44-9.

48. Gupta M, Mazumder, UK, Manikandan L, Haldar PK, Bhattacharya S, Kandar CC. Antibacterial activity of Vernonia cinerea. Fitoterapia 2003;74:148-50.

49. Manjulika Y, Sanjukta C, Kumar GS, Geeta W. Preliminary phytochemical screening of six medicinal plants used in traditional medicine. Int J Pharm Pharm Sci 2014;6:539-42. 